\title{
Determinants of Thai Airways passenger trust: A structural equation model analysis
}

\author{
Suchat Lainamngern \\ Sudaporn Sawmong \\ King Mongkut's Institute of Technology Ladkrabang (KMITL) \\ Faculty of Administration and Management \\ Bangkok, Thailand
}

\section{Keywords}

Customer relationship management; legacy airline; national carrier; perceived quality; perceived risk

\begin{abstract}
The authors undertook a study to investigate how customer relationship management (CRM), perceived service quality (PSQ), perceived risk (PER), and passenger expectations (PE) affected Thai Airways passenger trust (PT). The research instrument developed for the survey consisted of a questionnaire which used a seven-level agreement scale for the seven-part, 39 survey items. The study conducted both a confirmatory factor analysis (CFA) and a structural equation model (SEM) to analyze the 565 Thai Airways survey respondents' answers. A latent variable path analysis was performed using the LISREL 9.1 software program, with the model found to be consistent with empirical data. The causal factors in the model had both a positive and negative influence on the Thai Airways passenger trust, which can be explained $51 \%$ of the variance $\left(R^{2}\right)$ in passenger trust $(P T)$. The variables ranked in importance included perceived service quality (PSQ), customer relationship management (CRM), passenger expectations (PE), and perceived risk (PER), which had total values of $0.89,0.76,0.61$ and -0.36 , respectively.
\end{abstract}

Corresponding author: Suchat Lainamngern

Email addresses for the corresponding author: suchat.numngern@gmail.com

First submission received: $1^{\text {st }}$ September 2018

Revised submission received: $5^{\text {th }}$ October 2018

Accepted: $6^{\text {th }}$ December 2018

\subsection{Introduction}

On March 29, 1960, Thai Airways International Public Company Limited was established by the Thai government, as a joint venture (JV) between Thailand's domestic air carrier, Thai Airways Company (TAC) and Scandinavian Airlines System (SAS) (Thai Airways Annual Report, 2017). Initially, the company was registered as a limited company with TAC holding a $70 \%$ share, while SAS held a $30 \%$ share. On March 30, 1977, the JV came to an end when SAS transferred all of its shares to TAC, after which the airline raised further capital by selling its shares to Thailand's Ministry of Finance. On April 1, 1988, the domestic commercial air travel operations were merged with TAC, with the Ministry of Finance becoming the major shareholder. This was followed by the carrier becoming listed on the Stock Exchange of Thailand (SET) on July 19, 1991, through the conversion of its retained earnings into capital. Today, the national carrier is serving over 80 worldwide destinations.

Along with the expansion and public listing of the Kingdom's national carrier Thai Airways, came the explosive growth in international tourism. According to statistics from the Airports of Thailand (AOT), AOT handled 129.2 million passengers in 2017, an increase of 121.7 million in 2016 (The International Trade Administration, 2018). Additionally, there were 823,575 aircraft movements (takeoffs and landings) in 2017, an increase from 790,194 in 2016. Air cargo movements also showed a significant increase, rising to 1.60 million tons in 2017 from 1.45 million tons in 2016.

Commercial aviation, therefore, is a crucial sector for a nation's economy, with international aviation closely related to the expansion of tourism, of which $55 \%$ is done by air (United Nations, 2018). In 2016, International tourist arrivals (overnight visitors) reached 1.235 billion individuals, while international 
tourism receipts reached US\$1.2 trillion in the same year. Also, according to the United Nations (2018), international tourism generated an additional \$216 billion in exports through international air passenger transport services (rendered to non-residents), bringing the total value of tourism exports to US\$1.4 trillion, or US\$4 billion a day on average. This represents $7 \%$ of the world's exports of goods and services and $30 \%$ of services exports alone.

However, even in spite of these spectacular numbers, in the Thai Airways Annual Report (2017), it was stated that starting in 2014, Thai Airways faced various problems including decreased competitiveness, unprofitable routes outnumbering profitable ones, a wide range of aircraft types resulting in higher maintenance cost than the industry average, inefficient overall cost management, and inappropriate human resource management (HRM) and development. Moreover, the intense and fastchanging competitive condition of the airline business in the region caused the airline continued losses and the inability to recover.

Furthermore, low-cost carrier (LCC) competition has been tough year after year, with legacy national carriers such as Thai Airways, Malaysian Airways, and now even Singapore Airways finding profitability and market share ever more difficult to obtain (Srisook and Panjakajornsak, 2017). In 2017, LCC airlines consistently grew at a faster pace compared to the world's average growth, which in 2017 carried an estimated 1.2 billion passengers.

Also, in Southeast Asia, passenger traffic grew by approximately $10 \%$ in 2017, where six of the region's ten countries recorded double-digit growth. Additionally, Southeast Asian airlines now have 1,600 airplanes on order, in addition to an active fleet of close to 2,000 airplanes, with LCCs currently accounting for approximately $70 \%$ of Thailand's domestic seat capacity. In Thailand, the total domestic market has more than doubled over the past five years, driven by a combination of economic growth, an expanding middle class and rapid LCC expansion from approximately 11 million passenger seats in 2012, to 33 million in 2017 (Centre for Aviation, 2018).

As we can see, Thai Airways has significant challenges to overcome, both internally and externally. However, given the importance of the national carrier, the authors undertook a study to investigate how the variables related to customer relationship management (CRM), perceived service quality (PSQ), perceived risk (PER), and passenger expectations (PE) affected Thai Airways passenger trust (PT). It is hoped that from this research, a more sustainable and competitive solution will be found in boosting and retaining the airline's passenger trust.

\subsection{Literature Review}

\subsection{Customer relationship management (CRM)}

Customer relationship management is a competitive strategy that addresses the needs of consumers and integrates the way they interact with customers within the organization. CRM is also a streamlined business process that delivers value to customers, employees, and stakeholders (Brown, 2000). The core concept of CRM focuses on maintaining an existing customer base, by building relationships with customers in various ways. This is consistent with Venetia and Ghauri (2004) which concluded that service quality contributes to the maintenance of long-term relationships with customers.

Furthermore, Kumudha and Bhunia (2016), examined the Indian civil aviation sector and stated that PE refers to the preconceived ideas of a passenger about a product or service. Customer expectation is influenced by a customer's sensitivity to the product or service and can be fashioned by previous experience, advertising, hearsay, awareness of competitors, and brand image.

Zineldin (2005) evaluated CRM in the Swedish banking sector and stated that a crucial element in CRM is the quality realization, and the creation of value added is quality measurement and control, with the key factors in building a strong competitive position are through CRM, product/service quality, and differentiation.

Therefore, after a review of the relevant literature and theory related to customer relationship management (CRM), the following four observed variables were included in the research. These included service quality (x1), customer-focused strategy (x2), product image ( $\mathrm{x} 3)$, and customer relationship management (x4). Finally, the following two hypotheses were conceptualized for the research: 
H1: Customer relationship management (CRM) has a direct positive influence on passenger expectation (PE). $\mathrm{H} 2$ : Customer relationship management (CRM) has a direct positive influence on passenger trust (PT).

\subsection{Perceived service quality (PSQ)}

Early conceptualization of service quality was formed by Grönroos $(1983,1984)$, in which service quality was defined as the 'what' and 'how' of consumers receiving a service. Numerous subsequent authors have discussed perceived service quality, including Hutchins (1985, p.165), Zeithaml, Parasuraman and Berry (1990, p.16), and Juran and Gryna (1998), and have indicated that PSQ is a comparison between customer expectations in a product or service and their real perception. If the customer or customer sees that the product or service is the best and meets the expectations, it can be considered that the product or service is of good quality. In 1985, Parasuraman, Zeithaml, and Berry (1985) also published a conceptual model of service quality, which three years later was named 'SERVQUAL.' The service quality model (Parasuraman, 1998; Parasuraman, Zeithaml, and Berry, 1988) indicated that service quality could be measured through five functional quality dimensions, including reliability, assurance, tangibility, empathy, and responsiveness (RATER). Grönroos (1984), classified service quality into two groups, including expected service and perceived service. This included technical quality, in which functional quality is seen to be a very important dimension of a perceived service. There is also the element of 'functional quality' which is the 'how' component, where 'technical quality' is the 'what' (Kang, 2006).

This is consistent with Kotler (2000, p.200), which defined service as a person or organization's act or performance that is offered to another party that is not tangible, which does not result in something being owned. Furthermore, the OECD (2006) defined quality as the totality of characteristics of a product or service that have an impact on its ability to satisfy stated or implied needs. SERVQUAL has therefore been widely used to study the broader service industry, where the organization needs to understand the perceptions of its target audience in the service they need and is a technique that provides quality measurement (Ladhari, 2009). Haywood-Farmer (1988), followed up with research indicating that the three most important attributes in service quality were (1) physical facilities and processes (tangibility), (2) people's behavior (assurance), and (3) professional judgment (reliability).

Various other studies have also identified multiple latent variables as key to airline passenger repurchase intention. One such component is reliability, which Baker (2014) defined as the ability to provide passengers with services as promised without any assistance correctly. Reliability can also be described as the ability to perform service dependably and accurately, such as punctuality, the efficiency of the check-in process, and convenience and accuracy of reservations and ticketing (Kim and Lee, 2011).

Therefore, after a review of the relevant literature and theory related to perceived service quality (PSQ), the following three observed variables were included in the research. These included reliability (x5), assurance (x6), and tangibility (x7). Finally, the following two hypotheses were conceptualized for the research:

H3: Perceived service quality (PSQ) has a direct influence on passenger expectations (PE).

H4: Perceived service quality (PSQ) has a direct influence on passenger trust (PT).

\subsection{Perceived risk (PER)}

Early research concerning consumer perceptions of risk, indicated that getting to know the nature and range of the risk perceived by a consumer enables a better understanding of some of the aspects of consumer behavior (Cox, 1967). According to Jacoby and Kaplan (1972), numerous researchers have utilized the construct of PER to investigate various aspects of consumer behavior. From the research, five primary types of perceived risk were identified. These included financial, performance, physical, psychological, and social risk. Subsequently, a sixth PER was added. This came from Roselius (1971, p. 58), in which time loss was added. This was defined as "when some products fail, we waste time, convenience, and effort getting it adjusted, repaired, or replaced." Furthermore, Schiffman and Wisenblit (2015) stated that customers must find ways to reduce the risk of feeling empathetic when making a purchase decision and using the service. This is consistent with Kim, Ferrin, and Rao (2008), whose research in Hong Kong examined Internet consumers' trust and PER and determined that both have strong impacts on a consumer's purchasing decisions. Additionally, consumers' perceptions concerning trust, reputation, 
privacy concerns, security concerns, the information quality of the Website, and the company's reputation, have strong effects on an Internet consumers' trust in the Website.

Also, Chen and Chang (2013) in research conducted in Taiwan, indicated that investing resources in the increase of green perceived quality and the decrease of green perceived risk is used to enhance green satisfaction and green trust.

Therefore, after a review of the relevant literature and theory related to perceived risk (PER), the following three observed variables were included in the research. These included information perception $(\mathrm{x} 8)$, perceived risk of service (x9), and the perception of privacy (x10). Finally, the following two hypotheses were conceptualized for the research:

H5: Perceived risk (PER) has a direct influence on passenger expectations (PE).

H6: Perceived risk (PER) has a direct influence on passenger trust (PT).

\subsection{Passenger expectations (PE)}

Kumudha and Bhunia (2016), indicated that PE within the airline industry is the passenger's preconceived idea about the airline's product or service, with PE influenced by a customer's sensitivity of the product or service. This can be fashioned by previous experience, advertising, hearsay, competitor awareness, and the airline's brand image. Additionally, airline passengers expect efficiency, reliability, confidence in the staff, and personal attention. If a passenger's expectation is met, the outcome is customer satisfaction.

A consumer's expectation about an organization's services acts as a standard for the performance evaluation of that organization, with customers comparing their organization's performance expectation with the service offered. Furthermore, CRM can be improved through better analysis of the consumer's expectation of these services (Olshavsky and Kumar, 2001). This is also consistent with Heracleous and Wirtz (2010), which reported that carriers who wish to be successful must focus on passenger service.

Therefore, after a review of the relevant literature and theory related to perceived risk (PER), the following three observed variables were included in the research. These included work confidence (y4), management (y5), and service quality (y6). Finally, the following hypothesis was conceptualized for the research:

H7: Passenger expectations (PE) has a direct influence on passenger trust (PT).

\subsection{Passenger trust (PT)}

Morgan and Hunt (1994) stated that trust plays a significant role in determining commitment between customers and companies. Haryono et al. (2015) studied full-service carrier (FSC) passenger characteristics at the Adisutjipto International Airport Yogyakarta (JOG) in Java, Indonesia, and determined that service quality have a significant effect on trust, customer satisfaction, customer delight, and repurchase intention.

Furthermore, Chaudury and Holobrook (2001), reported that trust is essential to organizational effectiveness. The positive effects of work are the result of increased trust within the organization, resulting in increased employee productivity and organizational commitment (Nyhan and Marlowe, 1997). Trust is the basis of communication relationships in providing services to customers, with CT having a direct influence on customer loyalty (Marakanon and Panjakajornsak, 2017).

Therefore, after a review of the relevant literature and theory related to passenger trust (PT), the following three observed variables were included in the research. These included safety confidence (y1) management confidence (y2), and performance confidence (y3).

From the review of the literature and theory, the conceptual model for the study is presented in Figure 1. 


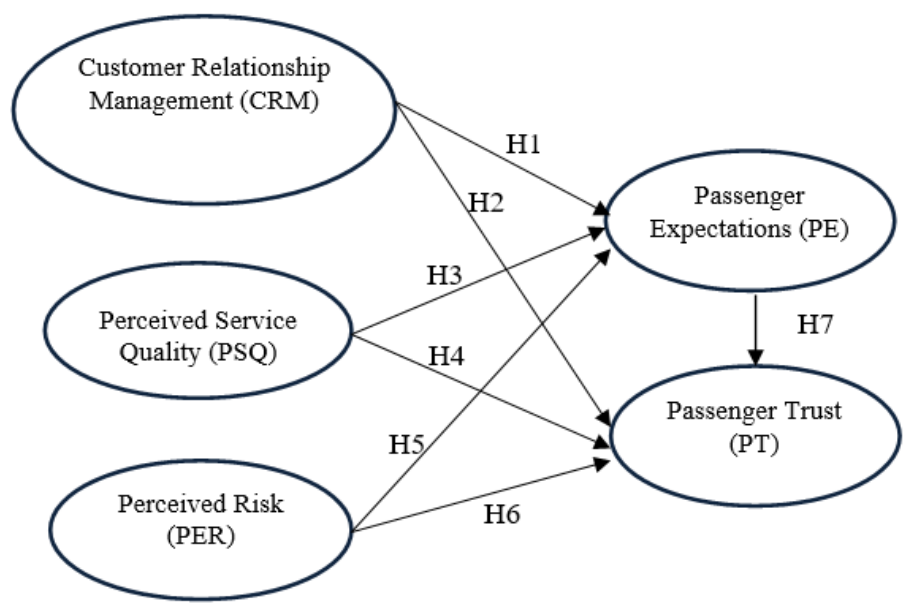

Figure 1. The conceptual model for Thai Airways passenger trust.

\subsection{Study objectives}

- To better understand how perceived service quality (PSQ), customer relationship management $(\mathrm{CRM})$, passenger expectations (PE), and perceived risk (PER) affect Thai Airway passenger trust (PT).

- To examine the significance of passenger expectations and perceptions about the CRM and marketing practices in full-service carrier (FSC) airlines.

\subsection{Methods}

\subsection{Population and sample}

A team of Thai university students was used to obtain a sample of 565 passengers from international and domestic travelers, both Thai and foreign, on Thailand's national full-service carrier (FSC), Thai Airways at Suvarnabhumi Airport from May to July 2014. As the Thai Airways passenger list was not available for public use, from the use of systematic sampling techniques, every $5^{\text {th }}$, check-in passenger was selected from individuals who had completed the check-in process from either the team's location at both the international and domestic terminals for Thai Airways.

Using a formula from Levine, Berenson and Krehbiel (2011), the required sample size was determined. Confirmation that 565 was highly reliable was also indicated by statistical sampling requirements from Krejcie and Morgan (1970), whose table of required sample sizes indicates that as the population increases, the sample size increases at a diminishing rate (plateau) and remains, eventually constant at slightly more than 380 cases. Therefore, there is little to be gained to warrant the expense and energy to sample beyond about 380 cases (Israel, 2013; Yamane, 1967). However, it is common to use larger sample sizes to increase researcher confidence.

\subsection{Qualitative research}

Furthermore, during the period between May to July 2014, qualitative research was further conducted by use of in-depth, semi-structured, guided interviews with five individuals including three university professors, and two individuals involved in executive management at Thai Airways. Their input covered the following five topics:

1. Measurement of perceived service quality (PSQ),

2. Measurement of customer relationship management (CRM),

3. Measurement of passenger expectations (PE),

4. Measurement of perceived risk (PER), and

5. Measurement of passenger trust (TR).

For the study, Cronbach's alpha (Tavakol and Dennick, 2011) was used to evaluate the initial 30 samples which used a 7-level, Likert type agreement scale (Matell and Jacoby, 1972), with '7' indicating 'strongly agree' and ' 1 ' indicating 'strongly disagree.' The value of alpha (a) that is considered acceptable ranges in value from 0 to 1 and may be used to describe the reliability of factors extracted from multi- 
point formatted questionnaires or scales, with a reliability score of 0.70 or higher being considered a reliable score by various researchers (Nunnally and Bernstein, 1994; Hair et al., 2016). From the study, alpha (a) was determined to average 75 .

\subsection{Research tool}

Questionnaire research design is an outline that is used to generate answers to research questions and is an arrangement of conditions of data collection and analysis. For this study, the authors used a descriptive survey methodology designed to assess how passengers trusted flying with the Kingdom's national FSC 'Thai Airways'. The design employed the self-administration of a 33-item questionnaire to a sample of individuals which was aimed at finding each's attitudes and opinion about how the 16 observed variables impacted passenger trust. Primary and secondary data was obtained, with primary data coming from data collected from the questionnaire. Secondary data was gathered from the documents, literature, websites, research articles, research reports, and

academic dissertations.

For queries that are designed to determine the value of the item comments, a 7-level Likert scale is often employed (Matell and Jacoby, 1972), with 1 representing an answer which 'strongly disagrees' with the item's statement, to 7, which is interpreted as an item statement in which the passenger 'strongly agrees'. Using the guidelines of Best and Kahn (2003), Table 1 presents the scale and values used in the study's questionnaire. The questionnaires collected from the 565 individuals indicated that the overall survey average was 'I more agree,' with an average of 5.65 overall. Furthermore, the survey's questionnaire utilized was divided into two sections (Matell and Jacoby, 1972). Part 1 consisted of 6 items pertaining to the passengers' demographics (Table 2, while Part 2 was divided into 7 sections with 33 items concerning perceived service quality (PSQ), customer relationship management (CRM), passenger expectation (PE), perceived risk (PR), and passenger trust (PT). There were 39 items in total.

\begin{tabular}{|c|l|c|}
\hline Level & \multicolumn{1}{|c|}{ Agreement Level Interpretation } & Mean Range \\
\hline 1 & Very low opinion & $1.00-1.49$ \\
\hline 2 & Low opinion & $1.50-2.49$ \\
\hline 3 & I agree somewhat & $2.50-3.49$ \\
\hline 4 & $\begin{array}{l}\text { I have a moderate level of } \\
\text { agreement }\end{array}$ & $3.50-4.49$ \\
\hline 5 & I agree & $4.50-5.49$ \\
\hline 6 & I more agree & $5.50-6.49$ \\
\hline 7 & I strongly agree & $6.50-7.00$ \\
\hline
\end{tabular}

Table 1: Thai Airways Passenger Agreement Scale

\subsection{Confirmatory factor analysis (CFA)}

After a review of research documents and relevant theory, a CFA analysis was used to test the interrelationships of the internal and external latent variables (Table 5). Confirmation analysis was conducted using the LISREL 9.1 software program, which indicated that the value of $\chi^{2}$ was not statistically significant $(p>0.05)$ with the $\chi 2 / \mathrm{df}<2.00$. Convergence validity was also adapted to measure the factor loadings of the observed variables and latent variables. Hooper, Coughlan, and Mullen (2008) and Hair et al. (2016) discussed low $\mathrm{R}^{2}$ values ( $\leq 0.20$ and $\leq 0.25$, respectively), and suggested that they are removed from the analysis, as this is an indication of high error rates. All factor loadings, however, showed values $>0.5$, indicating the consistency of the evaluating questions with respect to the suggested values ( $p$-value $>0.5$ ) (Fornell and Larcker, 1981). The reliability of each construct was also examined through CFA by using the composite reliability (CR) to measure the internal consistency of a single construct, marking all composite reliability (CR) values exceeding 0.6 , and stipulating the reliability of the measurement (Kline, 2011). Afterward, the validity of the model fit was also tested by using the average variance extracted (AVE). Furthermore, Steiger (1990) has indicated that the root mean square error of approximation (RMSEA) index compensates for model complexity. Also, the comparative fit index (CFI) was used which had a criterion of $\geq .95$, a standardized root mean square residual (SRMR) $\leq 0.05$, and a 
RMSEA as a measure of GOF in the models (Kline, 2011), as well as to measure the discrepancy per degree of freedom (Hu and Bentler, 1999).

\subsection{Results}

\subsection{Thai Airways passengers' descriptive analysis $(n=565)$}

For personal data (Table 2), it was found that $62.83 \%$ of the passengers were male, while $37.17 \%$ were female. A slight majority or $25.66 \%$ were between $35-44$ years old. Also, a significant number reported that they were Asian (44.60\%), with most indicating they were traveling on holiday (55.93\%).

\begin{tabular}{|c|c|c|}
\hline Item & Passengers & 96 \\
\hline \multicolumn{3}{|l|}{ Gender } \\
\hline male & 355 & 62.83 \\
\hline female & 210 & 37.17 \\
\hline Total & 565 & 100.00 \\
\hline \multicolumn{3}{|l|}{ Age } \\
\hline Less than 25 years old. & 16 & 2.83 \\
\hline 25-34 years old. & 90 & 15.93 \\
\hline $35-44$ years old. & 145 & 25.66 \\
\hline 45-54 years old. & 130 & 23.01 \\
\hline 55-64 years old. & 108 & 19.12 \\
\hline 65 years or older. & 76 & 13.45 \\
\hline Total & 565 & 100.00 \\
\hline \multicolumn{3}{|l|}{ Ethnicity } \\
\hline Asian & 252 & 44.60 \\
\hline European & 102 & 18.05 \\
\hline North American & 46 & 8.14 \\
\hline Middle Eastern & 89 & 15.75 \\
\hline Other & 76 & 13.45 \\
\hline Total & 565 & 100.00 \\
\hline \multicolumn{3}{|l|}{ Travel Purpose } \\
\hline Leisure/Holiday & 316 & 55.93 \\
\hline Business & 231 & 40.88 \\
\hline Other & 18 & 3.19 \\
\hline Total & 565 & 100.00 \\
\hline \multicolumn{3}{|l|}{ Profession } \\
\hline Business person & 189 & 33.45 \\
\hline Professional & 176 & 31.15 \\
\hline Service Provider & 135 & 23.89 \\
\hline Freelance / other & 65 & 11.50 \\
\hline Total & 565 & 100.00 \\
\hline \multicolumn{3}{|l|}{ Number of days } \\
\hline $1-3$ & 41 & 7.26 \\
\hline $4-6$ & 144 & 25.49 \\
\hline $7-9$ & 203 & 35.93 \\
\hline $10-12$ & 109 & 19.29 \\
\hline Over 12 days & 68 & 12.04 \\
\hline Total & 565 & 100.00 \\
\hline Average cost per day & \$US187.12 & \\
\hline
\end{tabular}

Table 2: Personal Characteristics Thai Airways Passenger Respondents ( $n=565)$

\subsection{Passenger's Response Information}

Table 3 shows that the mean scores and standard deviation of the factors that affect Thai Airways passenger trust (PT). The latent variables from the survey included CRM, PER, PSQ, PE, and PT. 
Interpreted results from the 7-point survey which ranged from 5.29 - 5.83 (Best and Kahn, 2003).

\begin{tabular}{|l|c|c|c|c|}
\hline Latent Variable & Items & $\overline{\mathbf{x}}$ & S.D. & Level \\
\hline Customer Relationship Management (CRM) & 8 & 5.83 & .45 & I more agree \\
\hline Perceived Risk (PER) & 6 & 5.60 & .41 & I more agree \\
\hline Perceived Service Quality (PSQ) & 6 & 5.84 & .42 & I more agree \\
\hline Passenger Expectations (PE) & 6 & 5.71 & .36 & I more agree \\
\hline Passenger Trust (PT) Total/Averages & 7 & 53.29 & .34 & I agree \\
\hline \multicolumn{1}{|c|}{ Ther } & 5.65 & 0.32 & I more agree \\
\hline
\end{tabular}

Table 3: Mean and Standard Deviation and Survey Interpretation

Note. $\bar{x}=$ the standard mean, S.D. $=$ Standard Deviation.

\subsection{Confirmatory factor analysis (CFA) results}

CFA analysis of the dependent and independent variables was built on the conceptual framework derived from the study of relevant documents and scholarly research (Figure 2 and Figure 3). By analyzing the confirmatory components with LISREL 9.1, $\chi 2$ was determined not to be statistically significant ( $p>0.05$ ), $\chi 2 / \mathrm{df}$ was $<2.00$, RMSEA $<0.05$, and SRMR $<0.05$. The goodness-of-fit index (GFI) was also indicated to be 0.99 , and the adjusted goodness-of-fit index (AGFI) was 0.97, which indicates a well-fitting model as their values are greater than 0.90 (Hooper et al., 2008). Furthermore, from Table 4 and Table 5, $\alpha$ was shown to range from 0.70 to 0.81 and CR was from 0.61 to 0.79. Hair et al. (2016) have also indicated that $\mathrm{R}^{2}$ values of 0.75 are significant, 0.50 are in the middle, and 0.25 are very weak.

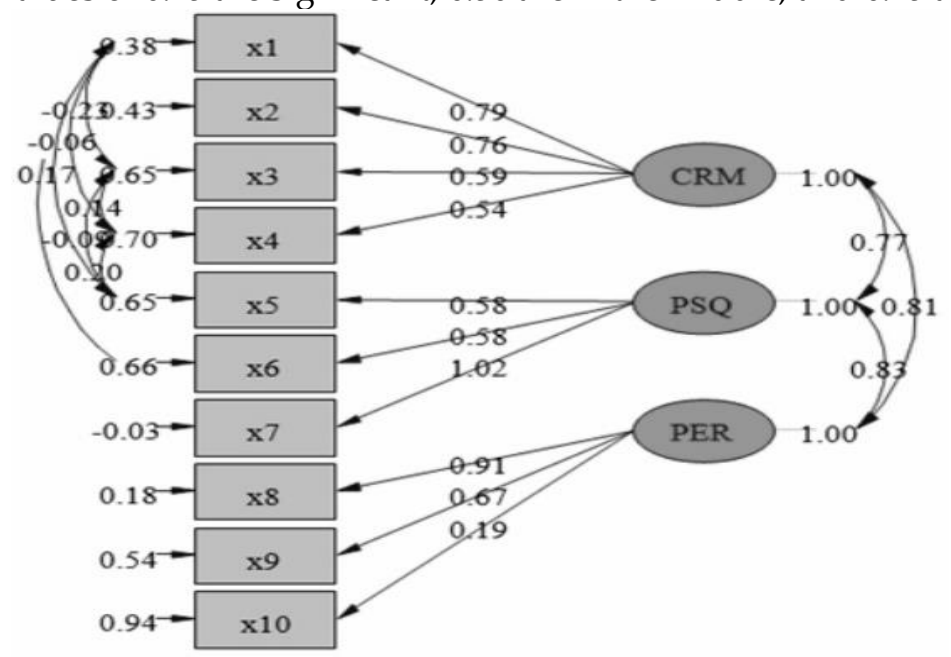

Figure 2. CFA of the external latent variables CRM, PSQ, and PER Note. Chi-Square $=6.29, \mathrm{df}=10, p$-value $=0.79053$, RMSEA $=0.000$

\begin{tabular}{|c|c|c|c|c|c|c|}
\hline constructs & $\alpha$ & CR & AVE & Observed variables & loading & $\mathbf{R}^{2}$ \\
\hline \multirow{4}{*}{$\begin{array}{l}\text { Customer } \\
\text { relationship } \\
\text { manageme } \\
\text { nt (CRM) }\end{array}$} & \multirow[t]{4}{*}{0.70} & \multirow[t]{4}{*}{0.77} & \multirow[t]{4}{*}{0.46} & service quality $(x 1)$ & 0.79 & 0.63 \\
\hline & & & & customer-focused strategy $(x 2)$ & 0.76 & 0.57 \\
\hline & & & & product image $(\times 3)$ & 0.59 & 0.35 \\
\hline & & & & $\begin{array}{l}\text { customer relationship } \\
\text { management }(x 4)\end{array}$ & 0.54 & 0.30 \\
\hline \multirow{3}{*}{$\begin{array}{l}\text { Perceived } \\
\text { service } \\
\text { quality } \\
\text { (PSQ) }\end{array}$} & \multirow[t]{3}{*}{0.70} & \multirow[t]{3}{*}{0.79} & \multirow[t]{3}{*}{0.57} & reliability $(x 5)$ & 0.58 & 0.34 \\
\hline & & & & assurance $(x 6)$ & 0.58 & 0.34 \\
\hline & & & & tangibility $(x 7)$ & 1.02 & 1.00 \\
\hline \multirow{3}{*}{$\begin{array}{l}\text { Perceived } \\
\text { risk (PER) }\end{array}$} & \multirow[t]{3}{*}{0.81} & \multirow[t]{3}{*}{0.65} & \multirow[t]{3}{*}{0.44} & information perception $(\times 8)$ & 0.91 & 0.82 \\
\hline & & & & perceived risk of service $(x 9)$ & 0.67 & 0.45 \\
\hline & & & & privacy perception $(\times 10)$ & 0.19 & 0.31 \\
\hline
\end{tabular}

Table 4: Confirming Elements of External Latent Variables 


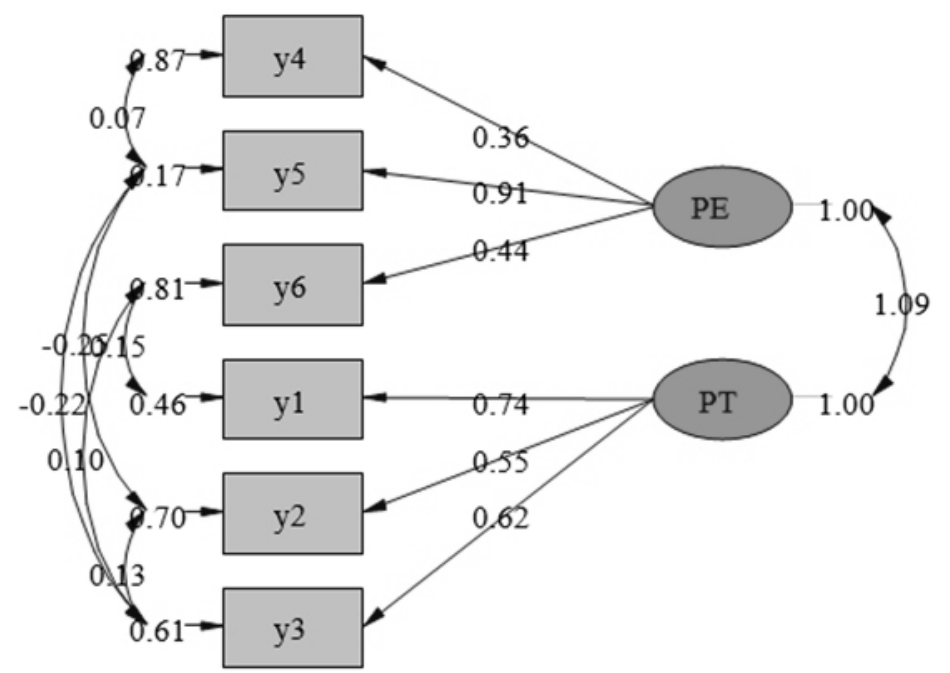

Figure 3. CFA of the internal latent variables PE and PT.

Chi-Square $=0.80, \mathrm{df}=2, p$-value $=0.67056, \mathrm{RMSEA}=0.000$

\begin{tabular}{|l|c|c|c|l|c|c|}
\hline \multicolumn{1}{|c|}{ constructs } & $\boldsymbol{\alpha}$ & CR & AVE & Observed variables & loading & $\mathbf{R}^{2}$ \\
\hline $\begin{array}{l}\text { Passenger } \\
\text { Expectations } \\
\text { (PE) }\end{array}$ & 0.74 & 0.61 & 0.38 & work confidence (y4) & 0.36 & 0.13 \\
\cline { 4 - 7 } & & & & management (y5) & 0.91 & 0.83 \\
\cline { 4 - 7 } $\begin{array}{l}\text { Passenger } \\
\text { Trust (PT) }\end{array}$ & 0.79 & 0.67 & 0.41 & safety confidence (y1) & 0.74 & 0.54 \\
\cline { 4 - 7 } & & & & $\begin{array}{l}\text { management confidence } \\
\text { (y2) }\end{array}$ & 0.55 & 0.30 \\
\cline { 4 - 7 } & & & & performance confidence (y3) & 0.62 & 0.39 \\
\hline
\end{tabular}

Table 5: Confirming Elements of Internal Latent Variables

\subsection{Convergent Model Analysis}

From the LISREL 9.1 analysis of the data, and the measurement of the five latent variables and their related hypotheses, it was determined that there was a good model fit with the empirical research data. Construct validity uses both convergent and discriminant validity in combination and must be used together to establish overall validity. Convergent validity can be analyzed in three ways. These include item reliability, composite reliability (CR), and average variance extracted (AVE) (Chau, 1997). As such, to assess the validity of the study's models, convergent validity and discriminant validity were used. Also, in SEM, a CFA is usually used to access construct validity (Jöreskog, Olsson, and Fan, 2016). Hair et al. (2016) and Byrne et al. (1989) have also indicated that factor loadings or regression weight estimates of latent to observed variables should have values higher than 0.50 , which indicates that all the constructs conform to the construct validity test and validity convergence.

The first measure, item reliability is indicated if items have significant factor loadings of 0.50 or above. The second measure, composite reliability, is assessed based on the criteria that the indicator's estimated pattern coefficient is significant for its underlying factor, which should have a threshold value for construct reliability at 0.60 or higher (Nunnally and Bernstein, 1994), with all AVE values higher than 0.50 (Hair et al., 2016).

Results in Table $x$ show that the $\chi 2$ value was 19.48, which had 21 degrees of freedom (df). Therefore, the ratio between $\chi 2$ and the $\mathrm{df}$ was equal to 0.93 when tested, which showed no statistical 
significance as it was $\geq 0.05$, which confirms the model's hypotheses are not different from the empirical data. Further confirmation was established as the results of the GFI $=0.99$, and the AGFI $=0.97$. The CFI was equal to 1.00. The RMSEA was equal to 0.000. The SRMR was equal to 0.02, which indicates an excellent fit as its value < 0.05 (Hu and Bentler, 1999).

\begin{tabular}{|l|l|c|l|l|}
\hline Criteria Index & Criteria & Values & Results & Supporting theory \\
\hline Chi-square: $\chi^{2}$ & $p \geq 0.05$ & 19.48 & passed & Rasch, 1980 \\
\hline Relative Chi-square: $\chi^{2} / \mathrm{df}$ & $\leq 2.00$ & 0.93 & passed & Byrne et al.,1989 \\
\hline GFI & $\geq 0.90$ & 0.99 & passed & Jöreskog et al., 2016. \\
\hline AGFI & $\geq 0.90$ & 0.97 & passed & Hooper et al., 2008 \\
\hline SRMR & $\leq 0.05$ & 0.02 & passed & Hu and Bentler, 1999 \\
\hline RMSEA & $\leq 0.05$ & 0.00 & passed & Hu and Bentler, 1999. \\
\hline CFI & $\geq 0.90$ & 1.00 & passed & $\begin{array}{l}\text { Schumacker and } \\
\text { Lomax, 2010 }\end{array}$ \\
\hline Cronbach's Alpha & $\geq 0.70$ & 0.75 & passed & $\begin{array}{l}\text { Tavakol and } \\
\text { Dennick, 2011. }\end{array}$ \\
\hline
\end{tabular}

Table 6: Criteria and Theory of the Values of Goodness-of-Fit Appraisal.

The validated results are detailed in Table 7 and Table 8, as well as Figure 4 .

\begin{tabular}{lccccc}
\hline Variable & CRM & PER & PSQ & PE & PT \\
\hline CRM & $\mathbf{1}$ & & & & \\
PER & $.64^{\text {** }}$ & $\mathbf{1}$ & & & \\
PSQ & $.66^{\text {** }}$ & $.64^{\text {** }}$ & $\mathbf{1}$ & & \\
PE & $.68^{\text {** }}$ & $.68^{\text {** }}$ & $.72^{\text {** }}$ & $\mathbf{1}$ & \\
PT & $.31^{\text {}}$ & $.61^{\text {** }}$ & $.32^{\text {** }}$ & $.43^{\text {** }}$ & $\mathbf{1}$ \\
\hline$\rho_{\mathrm{C}}($ Construct & 0.76 & 0.58 & 0.81 & 0.54 & 0.63 \\
Reliability) & & & & & \\
$\rho_{\mathrm{V}}(\mathrm{AVE})$ & 0.44 & 0.34 & 0.60 & 0.31 & 0.38 \\
$\sqrt{\mathrm{AVE}}$ & 0.66 & 0.58 & 0.77 & 0.56 & 0.62 \\
\hline
\end{tabular}

Table 7: Correlation Coefficients between Latent Variables (under the diagonal) Construct Reliability $(\rho C)$ and the Average Variance Extracted (AVE)

Note: AVE is shown on the diagonal of the matrix (in bold). Square of inter-construct correlation is shown under the diagonal. **Sig. $<.01$.

The results of hypotheses testing for this study are shown in Figure 4 and Tables 8 and 9.

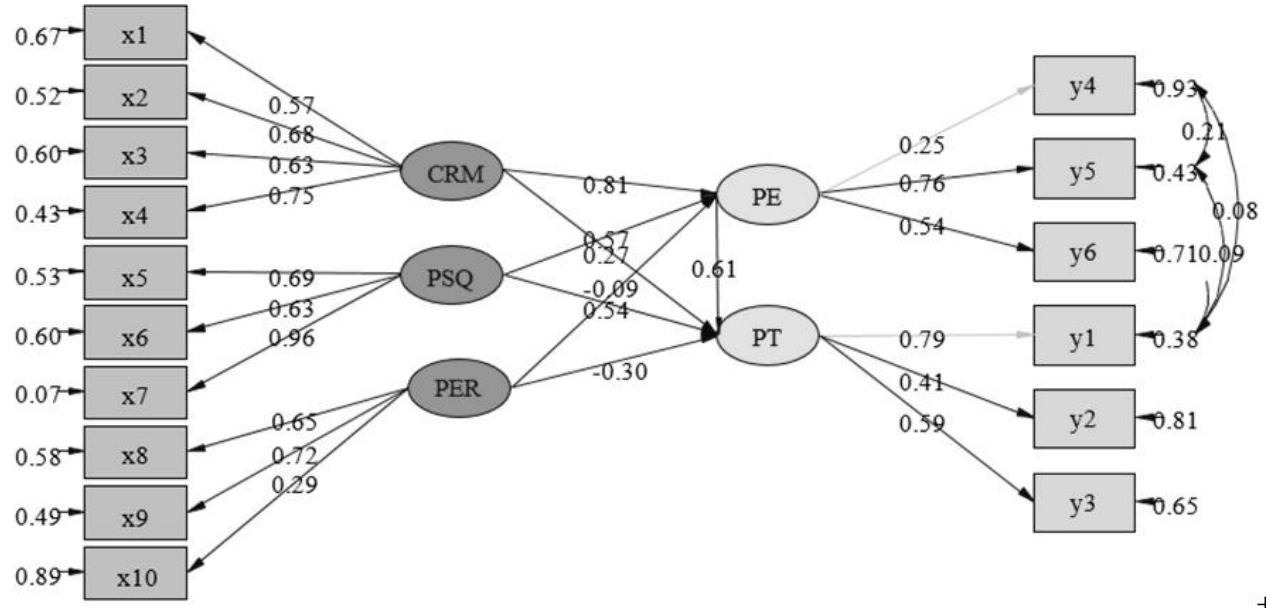

Figure 4. SEM of variables affecting Thai Airways passenger trust

Note. Chi-Square $=19.48, \mathrm{df}=21, p$-value $=0.55421$, RMSEA $=0.000$ 
Additionally, the direct effect (DE), indirect effect (IE), and total effects (TE) of the latent variables (PE, PSQ, PER, and CRM) on Thai Airways passenger trust (PT) are shown in Table 8.

\begin{tabular}{|c|c|c|c|c|c|c|}
\hline \multirow{2}{*}{$\begin{array}{c}\text { Dependent } \\
\text { variables }\end{array}$} & \multicolumn{6}{|c|}{ Independent Variables } \\
\hline & & $\mathbf{R}^{2}$ & PE & PSQ & PER & CRM \\
\hline \multirow{3}{*}{ PT } & $\mathrm{DE}$ & \multirow{3}{*}{.14} & $0.61^{*}$ & $0.54^{*}$ & $-0.30^{*}$ & $0.27^{*}$ \\
\hline & IE & & - & $0.35^{*}$ & -0.06 & $0.49^{*}$ \\
\hline & $\mathrm{TE}$ & & $0.61^{*}$ & $0.89^{* *}$ & $-0.36^{*}$ & $0.76^{*}$ \\
\hline \multirow{3}{*}{ PE } & $\mathrm{DE}$ & \multirow{3}{*}{.38} & & $0.57^{\star \star}$ & -0.09 & $0.81^{\star *}$ \\
\hline & IE & & & - & - & - \\
\hline & TE & & & $0.57^{\star *}$ & -0.09 & $0.81^{*}$ \\
\hline
\end{tabular}

Table 8: Standard Coefficients of Influence in the Structural Equation Model of

Variables Affecting Thai Airways Passenger Trust

Note. *Sig. $<0.05, * *$ Sig. $<0.01$.

Because the model is consistent with empirical data, PT can explain the variance of factors affecting the confidence of Thai Airways passengers $\left(R^{2}\right)$ by $51 \%$. Causes that affect PT were PSQ, CRM, PE, and PER, which had total effects (TE) of $0.89,0.76,0.61$ and -0.36 , respectively (Table 8). Table 9 presents the results of final model hypotheses testing.

\begin{tabular}{|l|c|c|c|}
\hline \multicolumn{1}{|c|}{ Hypotheses } & Coef. & t-test & Results \\
\hline $\begin{array}{l}\text { H1: Customer relationship management (CRM) has a } \\
\text { direct influence on customer expectation (EXP). }\end{array}$ & 0.81 & $3.20^{* *}$ & supported \\
\hline $\begin{array}{l}\text { H2: Customer relationship management (CRM) has a } \\
\text { direct influence on passenger trust (PT). }\end{array}$ & 0.27 & $2.07^{*}$ & supported \\
\hline $\begin{array}{l}\text { H3: Perceived service quality (PSQ) has a direct } \\
\text { influence on passenger expectations (PE). }\end{array}$ & 0.57 & $4.32^{\text {** }}$ & supported \\
\hline $\begin{array}{l}\text { H4: Perceived service quality (PSQ) has a direct } \\
\text { influence on passenger trust (PT). }\end{array}$ & 0.54 & $2.82^{\text {** }}$ & supported \\
\hline $\begin{array}{l}\text { H5: Perceived risk (PER) has a direct influence on } \\
\text { passenger expectations (PE). }\end{array}$ & -0.09 & -0.37 & unsupported \\
\hline $\begin{array}{l}\text { H6: Perceived risk (PER) has a direct influence on } \\
\text { passenger trust (PT). }\end{array}$ & -0.30 & $-2.18^{*}$ & supported \\
\hline $\begin{array}{l}\text { H7: Passenger expectations (PE) have a direct influence } \\
\text { on passenger trust (PT) }\end{array}$ & 0.61 & $2.05^{*}$ & supported \\
\hline
\end{tabular}

Table 9: Results of the Hypothesis Testing Note. *Sig. $<0.05, * *$ Sig. $<0.01$.

\subsection{Discussion and conclusion}

In recent times, the quality of life of air transportation services (ATS) has always been one of the predominant factors that determine a nation's economic progress. Therefore, a well-managed ATS serves as a catalyst for economic transformation (Kumudha and Bhunia, 2016). In Thailand, commercial aviation statistics are particularly impressive, as in 2016122 million passengers transited a Thai AOT (Airports of Thailand) operated airport (Kositchotethana, 2017).

Furthermore, based on the results of the study's SEM variables affecting Thai Airways passenger trust, it was found that all causal factors in the model had a positive influence, which can be explained by the $51 \%$ of variance in passenger trust $\left(R^{2}\right)$. The variables ranked in importance included perceived service quality (PSQ), customer relationship management (CRM), passenger expectations (PE), and perceived risk (PER) had a total value of $0.89,0.76,0.61$ and -0.36 , respectively.

\subsection{Perceived service quality (PSQ)}

Reasons for the high importance placed by Thai Airways passengers' on PSQ is that it is a comparison between the customer's expectations in the product or service and their actual perception (Ali, 2018). If the customer or customer sees that the product or service is the best and meets the expectations, they will continue to use it (Hutchins, 1985, p.165; Juran and Gryna, 1998; Zeithaml et al., 1990, p.16). This 
is consistent with Chou, Liu, Huang, Yih, and Han (2011), which viewed airline service quality in Taiwan as a key to a successful airline.

Multiple studies have also reported that passenger service quality satisfaction is contingent on how an airline responds to passenger needs (Lerrthaitrakul and Panjakajornsak, 2014). Furthermore, Moreover, past passenger perceptions service quality satisfaction could significantly influence a passenger's decision when choosing the same airline again (Park, Robertson, and Wu, 2004; Yang, Hsieh, and Yang, 2012).

Additionally, Gefen (2002) discussed customer loyalty in e-commerce, using components of the RATER (SERQUAL) model, and determined that responsiveness, reliability, and assurance played key roles. This is consistent with this study's survey of Thai Airways passengers in which Part 4's PSQ item 3 had a mean score of 6.38 (the second highest of the survey) when passengers were asked to respond to the statement 'Thai Airways delivers prompt service.'

\subsection{Customer relationship management (CRM)}

From the study, Thai Airways passengers placed CRM as second in importance, as an airlines digital behavior and the associated technological environment are increasingly having a significant impact on the way companies manage their customer relationships (Krämer, Tachilzik and Bongaerts, 2017; Wan, 2017). This is consistent with Brown (2000), which indicated that CRM is a competitive strategy, and focus needs to be given to be given to consumers. It is also a business process improvement that delivers value to customers, employees, and stakeholders.

Vuthisopon and Srinuan (2017) discussed the impact of E-Service Quality (ESQ) within the Thai Low-Cost Carrier (LCC) airline sector, and also confirmed that the most important things are airline security standards and services on board. Additionally, when customers book seats online, confirmation messages should be sent to their mobile phones automatically. Also, channels of payment should be increased, airline office online hours' contact should be extended in order that customers can contact the LCC office at any time, and in the case of problems or delays in check-in, solutions must be found quickly in order to increase competence in services and LCC competitiveness. However, e-commerce vendors using online systems need to convince their customers that both the vendors and systems are trustworthy (Järveläinen, 2007). This is consistent airline e-ticketing research from Lau, Kwek and Tan (2011), which indicated that airline e-ticketing was comprised of five variables. These included ease of use, website design, assurance, responsiveness, and personalization.

\subsection{Passenger expectations (PE)}

In Hong Kong, Gilbert and Wong (2003) investigated airline passenger expectations (PE) and discovered there were significant differences among passengers of different ethnic groups/nationalities, as well as among passengers who travel for business, for a holiday, or to visit their family. Additionally, these Asian travelers consistently ranked 'assurance' as the most important service dimension, with passengers concerned about safety and security. This is consistent with this study's survey of Thai Airways passengers in which Part 5's PE item 3 had a mean score of 6.54 (the highest of the survey) when passengers were asked to respond to the statement 'Thai Airways provides the right kind of service.'

Therefore, customer satisfaction is the outcome felt by those that have experienced a company's performance that have fulfilled their expectations (Angelova and Zekiri, 2011), with expectations playing an important role in the satisfaction formation. Kotler (2000) earlier stated that satisfaction is related to how a person's feeling of pleasure or disappointment resulting from comparing a product's perceived performance to their perceived expectations. Additionally, Cronin and Taylor (1992), stated that expectations serve as a reference point in a customer's assessment of performance.

\subsection{Perceived risk (PER)}

Knowledge of the sources and character of consumer PER is of great importance for companies. Schiffman and Kanuk (1994), reported that the scale and type of consumer reaction depends on the perceived level of risk, and on his or her level of tolerance for the perceived risk. Also, PER is the ability to assess the risks consumers face in purchasing a product or service (Kotler and Armstrong, 2002).

From the study on Thai Airways passenger trust, PER has a mean score of 5.60. From the six survey items concerning PER, 'I am aware of Thai Airways service, and flight schedules' (5.75) seemed to have the greatest importance. This can be interpreted as 'uncertainty is not good.' This is consistent with Chang and 
Chen (2008), which argued that a reduction in PER, leads to an increase in purchase probability. Therefore, a decrease in PER helps in increasing customer trust.

In other studies, Alessandro, Girardi and Tiangsoongnern (2012) examined the effect of risk perception and trust on online shopping behavior. The research found that Internet Fraud Protection has a positive impact on online shopping trust, with PER having a negative impact on trust when the Internet is used to buy products or services. This is important for airlines as passengers want to reduce their risk when using online payment systems and should be afforded high levels of security to reduce their perceptions of risk.

\subsection{Passenger trust (PT)}

In the Libyan airline industry, Ehbara and Shukor (2016) investigated service quality and customer trust and determined that there is positive relationship between the service quality factors and customer trust, except when it came to employee competence. Shared values and benevolence of service quality factors were found to have high influences on customer trust. Additionally, other studies have confirmed that customer trust, attachment, integrity, and positive word of mouth, has a positive effect on customer loyalty (Ahrens, Coyle and Strahilevitz, 2013; de Villiers, 2015; Lai, 2015).

Chen, Liu, Sheu, and Yang (2012) conducted a study on factors affecting customer satisfaction in the financial services industry and reported that service awareness and fair service are essential elements to customer satisfaction. Additionally, service fairness, perceived service quality, and customer perceived value have a positive effect on customer trust. Gregg and Walczak (2010) studied the relationship between site qualities, trust and price increase in online auctions, and reported that Web site quality is positively correlated with trust in online auctions. This was consistent with Yi, Yoon, Davis and Lee (2013) that perceived information quality has a positive effect on trust, while perceived risk has a negative effect on trust.

\subsection{Limitations and direction for future research}

The present research on airline passenger trust can be a starting point for a new direction in studying the role of social media in customer loyalty programs, as social media platforms are becoming a critical element in an airline's success in providing customer services to its passengers and stakeholders. Numerous studies have determined that time is of the essence to FSA passengers, and social media is becoming the platform of choice. Furthermore, an investigation into how these social media services are dependent on multi-lingual staff in an international environment and how these personnel can be obtained is also necessary. Possible research could also be conducted into how out-sourcing can play a role in this capability outside the parent airline's base and country of origin.

Additionally, the following limitations of the study are as follows:

- This study was limited to Thai Airways' passengers only, who were transiting Thai Airways terminals at Bangkok's Suvarnabhumi Airport.

- Accuracy of the data collection process was contingent on whether or not the research team who administered the questionnaire followed the guidelines presented by the researchers.

- From the analysis of other research, it was determined that FSC and LCC passengers have significantly different demographics (age, sex, etc.). Therefore, more research needs to be undertaken as to how this factor can be used to both obtain and retain FSC passengers.

- There also needs to be further research on how aircraft age and cabin services affect passenger satisfaction and trust in the airline. It is being suggested by the current executives at Thai Airways and government officials responsible for its operation, that this is a critical element in passenger retention. Therefore, further research needs to be conducted on the specifics of this.

- As also suggested, social media is playing an ever-increasing role, but investigation needs to be undertaken into how to protect the customer data and secure the platforms from hacks and virus attacks.

Care was taken throughout the research process to eliminate or at least minimize the stated and unforeseen limitations of the study. 


\section{References}

Ahrens, J., Coyle, J. R. and Strahilevitz, M. A. (2013). Electronic word of mouth: The effects of incentives on e-referrals by senders and receivers. European Journal of Marketing, 47(7), pp. 1034 - 1051. Available at: doi: 10.1108/03090561311324192

Alessandro, S., Girardi, A. and Tiangsoongnern, L. (2012). Perceived risk and trust as

antecedents of online purchasing behavior in the USA gemstone industry. Asia Pacific Journal of Marketing and Logistics, pp. 433-460. Available at: doi: 10.1108/13555851211237902

Ali, Q. (2018). Service quality from customer perception: Comparative analysis between Islamic and conventional bank. Journal of Marketing and Consumer Research, 43, pp. 70 - 82. Available at: https://tinyurl.com/ybvutn5a [Accessed 25 Sep. 2018].

Angelova, B. and Zekiri, J. (2011). Measuring customer satisfaction with service quality using American Customer Satisfaction Model (ACSI Model). International Journal of Academic Research in Business and Social Sciences, 1(3), pp. 232 - 258. Available at: doi: 10.6007/ijarbss. v1i2.35

Baker, D. (2014). Low-cost airlines management model and customer satisfaction. International Journal of Economics, Commerce, and Management, 2(9), pp. 1 - 17. Available at: http://tinyurl.com/jxg2ymb [Accessed 25 Sep. 2018].

Best, J. W. and Kahn, J. V. (2003). Research in Education. 10th ed., New Jersey: Pearson Education.

Brown, S. A. (2000). Customer Relationship Management: A Strategic Imperative in the world of e-Business. Toronto, Canada: John Wiley and Sons.

Byrne, B. M., Shavelson, R. J. and Muthén, B. (1989). Testing for the equivalence of factor covariance and mean structures: The issue of partial measurement invariance.

Psychological Bulletin, 105(3), pp. 456-466. Available at: doi: 10.1037//0033-2909.105.3.456

Centre for Aviation. (2018). Thailand low-cost airlines: Rapid growth as fleet triples in 5 years. Available at: https://tinyurl.com/y7b76dda [Accessed 25 Sep. 2018].

Chang, H. H. and Chen, W. W. (2008). The impact of online store environment cues on purchase intention, trust, and perceived risk as a mediator. Online Information Review, 32(6), pp. 818-841. doi: 10.1108/14684520810923953 [Accessed 25 Sep. 2018].

Chau, P. Y. K. (1997). Reexamining a model for evaluating information center success using a structural equation modeling approach. Decision Sciences, 28(2), pp. 309 - 334. Available at: doi: 10.1111/j.1540-5915.1997.tb01313.x

Chaudury, A. and Holbrook, M. B. (2001). The chain of effects from brand trust and brand affect to brand performance: the role of brand loyalty. Journal of Marketing, 65(2), pp. 81-93. Available at: doi: 10.1509/jmkg.65.2.81.18255

Chen, Y-S. and Chang, C-H. (2013). Towards green trust: The influences of green perceived quality, green perceived risk, and green satisfaction. Management Decision, 51(1), pp. 63-82. Available at: doi: 10.1108/00251741311291319

Chen, H-G., Liu, J. Y-C., Sheu, T. S. and Yang, M-H. (2012). The impact of financial services quality and fairness on customer satisfaction. Managing Service Quality:

An International Journal, 22(4), pp. 399-421. Available at: doi: 10.1108/09604521211253496

Chou, C-C., Liu, L-J., Huang, S-F., Yih, J-M. and Han, T-C. (2011). An evaluation of airline service quality using the fuzzy weighted SERVQUAL method. Applied Soft Computing, 11(2), pp. 2117 - 2128. Available at: doi: 10.1016/j.asoc.2010.07.010

Cox, D. F. (1967). Introduction. In: D.F. Cox, ed., Risk taking and information handling in consumer behavior. Boston, MA: Harvard University Press, p. 15.

Cronin, J. J. and Taylor, S. A. (1992). Measuring Service Quality: A Reexamination and Extension. Journal of Marketing, 56(3), pp.55 - 68. Available at: doi: 10.2307/1252296

De Villiers, R. (2015). Customer brand enmeshment: Typography and complexity modeling of customer brand engagement and brand loyalty enactments. Journal of Business Research, 68(9), pp. 1953 - 1963. Available at: doi: 10.1016/j.jbusres.2015.01.005

Ehbara, R. A. and Shukor, S. A. (2016). Impact of service quality factors on customer trust in Libyan airline industry. International Journal of Academic Research in Business and Social Sciences, 6(5), pp.350-363. Available at: doi: $10.6007 /$ ijarbss/v6-i5/2153

Fornell, C. and Larcker, D. F. (1981). Evaluating structural equation models with unobservable variables and measurement error. Journal of Marketing Research, 18(1), pp. 39-50. Available at: doi: 10.2307/3151312

Gefen, D. (2002). Customer loyalty in e-Commerce. Journal of the Association for Information Systems, 3(1), pp. 27 - 51. Available at: https://tinyurl.com/y7rbjvcx [Accessed 25 Sep. 2018].

Gilbert, D. and Wong, R. K. C. (2003). Passenger expectations and airline services: A Hong Kong-based study. Tourism Management, 24(5), pp. 519-532. Available at: doi: 10.1016/s0261-5177(03)00002-5

Gregg, D. G. and Walczak, S. (2010). The relationship between website quality, trust and price premiums at online auctions. Electronic Commerce Research, 10(1), pp. 1-25. Available at: doi: 10.1007/s10660-010-9044-2 
Grönroos, C. (1983). Strategic management and marketing in the service sector. Marketing Science Institute, pp. 83 104. Available at: https://tinyurl.com/y8cq3agc

[Accessed 25 Sep. 2018].

Grönroos, C. (1984). A service quality model and its marketing implications. European Journal of Marketing, 18(4), pp. 36-44. Available at: doi: 10.1108/EUM0000000004784

Hair, J. F., Hult, G. T. M., Ringle, C. and Sarstedt, M. (2016). A primer on partial least quares structural equation modelling (PLS-SEM). Thousand Oaks, CA: Sage.

Haryono, S., Suharyono, Fauzi, A. D. H. and Suyadi, I. (2015). The effects of service quality on customer satisfaction, customer delight, trust, repurchase intention, and word of mouth. European Journal of Business and Management, 7(12), pp. 36 - 48. Available at: http://tinyurl.com/hgpqhw2 [Accessed 25 Sep. 2018].

Haywood-Farmer, J. (1988). A conceptual model of service quality. International Journal of Operations and Production Management, 8(6), pp. 19-29. Available at: doi: 10.1108/eb054839

Heracleous, L. and Wirtz, J. (2010). The Globe: Singapore Airlines' balancing act. Harvard Business Review, July-August. Available at: http:/ / tinyurl.com/zd9esrq [Accessed 25 Sep. 2018].

Hooper, D., Coughlan, J. and Mullen, M. (2008). Structural equation modelling: Guidelines for determining model fit. Electronic Journal of Business Research Methods, 6(1), pp. 53-60. Available at: http://tinyurl.com/zyd6od2 [Accessed 25 Sep. 2018]. 